Article

\title{
Pain Relief and Antimicrobial Activity in Alveolar Osteitis after Platelet-Rich Fibrin Application-A Non-Randomized Controlled Study
}

\author{
Damian Chybicki and Anna Janas-Naze *
}

Citation: Chybicki, D.; Janas-Naze, A. Pain Relief and Antimicrobial Activity in Alveolar Osteitis after Platelet-Rich Fibrin Application-A Non-Randomized Controlled Study. Appl. Sci. 2022, 12, 1324. https:// doi.org/10.3390/app12031324

Academic Editors: Gaspare Palaia and Vittorio Checchi

Received: 29 December 2021

Accepted: 24 January 2022

Published: 26 January 2022

Publisher's Note: MDPI stays neutral with regard to jurisdictional claims in published maps and institutional affiliations.

Copyright: (c) 2022 by the authors Licensee MDPI, Basel, Switzerland. This article is an open access article distributed under the terms and conditions of the Creative Commons Attribution (CC BY) license (https:/ / creativecommons.org/licenses/by/ $4.0 /)$.
Department of Oral Surgery, Central Clinical Hospital, Medical University of Lodz, Pomorska 251, 92-213 Lodz, Poland; damian.chybicki@gmail.com

* Correspondence: anna.janas@umed.lodz.pl; Tel.: +48-426757529

Featured Application: Application of platelet-rich fibrin provides better pain relief in alveolar osteitis than does the application of aspirin cones; bacterial concentrations in extraction wounds are consistent with the pain relief experienced.

\begin{abstract}
The objective was to compare pain relief in alveolar osteitis achieved by the application of platelet-rich fibrin (PRF) and aspirin cones, and to assess the influence of both treatments on bacterial concentrations in post-extraction wounds. A split-mouth, single-center, non-randomized controlled trial was conducted in 30 patients. Pain relief was assessed using the visual analog scale at three time points (before, $24 \mathrm{~h}$ after, and $48 \mathrm{~h}$ after intervention). Bacterial concentrations were evaluated from cultures of swab samples collected at the three time points. A Wilcoxon matched-pairs signed-rank test was performed to detect differences in distributions of scalar variables between treatment with PRF and aspirin cones. Pain relief at $24 \mathrm{~h}$ and $48 \mathrm{~h}$ after treatment was significantly higher $(p=0.003)$ with PRF application than with aspirin cone placement. Additionally, PRF application caused a significantly higher reduction in aerobic bacteria concentration, an average increase, instead of a decrease, in lactic acid bacilli concentration in the first $24 \mathrm{~h}$, and a significantly greater increase in streptococci concentration at $48 \mathrm{~h}$ follow-up. PRF provides better pain relief than aspirin cones in alveolar osteitis. Bacterial concentrations in the extraction wounds are consistent with the pain relief achieved after PRF or aspirin application.
\end{abstract}

Keywords: alveolar osteitis; dry socket; platelet rich fibrin; antimicrobial effect

\section{Introduction}

Alveolar osteitis (also known as dry socket) is an unavoidable complication in clinics because tooth extraction remains one of the most common procedures in oral surgery. Hence, a noticeable emphasis is placed on understanding the mechanism behind alveolar osteitis and on searching for new methods of rapid tissue restoration and pain relief [1-3]. This complication was first described by Crawford in 1896 [2]. One of the most widely accepted mechanisms of dry socket occurrence is an increased fibrinolytic activity resulting from traumatic extraction, tobacco use, contraceptives and a pre-extraction infection, which leads to a premature loss of the alveolar clot. Fibrinolysis results from the activation of plasminogen into plasmin and can be achieved by direct (physiological) and indirect (nonphysiological) mechanisms. Direct activators are released from tissues upon injury, while indirect activators are of bacterial origin. Nevertheless, the etiology of the dry socket is not fully understood [1]. Pain is the fundamental and primary symptom of dry sockets; occasionally, the acute and severe nature of the pain can prevent a patient from performing professional and social activities. This neuralgic type of pain can occur anytime between the first and third day after the extraction of permanent teeth and increases with time [1,4]. Managing dry socket is challenging for clinicians because it occurs frequently with an 
incidence rate ranging from 1-30\%, depending on the scope of surgery (routine extraction or impacted teeth surgery) [5,6].

Various studies explored the etiology and treatment for dry socket [4,7-10]. One extensively researched treatment option is the application of platelet-rich fibrin (PRF), a biomaterial often used in oral surgery [8,10-14]. However, to the best of our knowledge, no study has yet analyzed the number of bacteria in tooth extraction wounds after the application of PRF in alveolar osteitis and the correlation between bacterial growth and pain relief in this treatment method. We aimed to address this knowledge gap through a non-randomized clinical trial with two objectives: first, to compare pain relief in alveolar osteitis after the application of PRF and aspirin cones, and second, to analyze bacterial concentrations in the extraction wound after the application of each treatment. A contemporary review of literature points out that a large number of studies were reported regarding the use of PRF and its advantages in many fields of oral surgery [5,6,8,10-14]. On the basis of these conclusions, we adopted the hypothesis that PRF will prove its better healing and antimicrobial properties than the routinely used acetylsalicylic acid cones.

\section{Materials and Method}

\subsection{Study Design}

A split-mouth, non-randomized controlled trial was conducted in the Department of Oral Surgery, Medical University of Lodz, Poland over a period of 17 months from January 2020 to July 2021. The study was performed after approval from the Bioethical Committee of Medical University of Lodz (RNN/369/18/KE), in compliance with Helsinki Declaration and after the acquisition of informed consent from the participants.

It was decided a priori that if dry socket was diagnosed following a tooth extraction, aspirin cones (Nipas, Galena, Wroclaw, Poland) would be applied. In case of a subsequent extraction of a homonymous tooth and reoccurrence of dry socket, patients would be treated with a PRF application.

\subsection{Patient Selection}

Adult patients with homonymous teeth who qualified for extraction and experienced a dry socket after extraction were included in the study. Patients with systemic diseases, patients allergic to acetylsalicylic acid, pregnant and/or lactating women, patients taking any drugs known to affect the number or function of platelets, patients with abnormal platelet counts, and patients with a history of antibiotic or anti-inflammatory therapy for dry socket were excluded from the study. Additionally, patients who had received any kind of treatment for dry socket before the study was initiated were excluded.

\subsection{Intervention}

The socket was rinsed with saline and inspected for any remaining debris before placing the material. One aspirin cone consisted of $32 \mathrm{mg}$ of acetylsalicylic acid as the active ingredient. Two cones were used for premolars and three for molars. The PRF material was obtained by collecting the patient's blood from the elbow fossa into $9 \mathrm{~mL}$ vacuum tubes. The collected blood was centrifuged in a centrifuge (Hettich EBA 200) suitable for obtaining PRF material at $2690 \mathrm{rpm}$ for $12 \mathrm{~min}$. After placing the treatment material, the wound was sutured.

\subsection{Assessing Impact of PRF on Pain Relief in Dry Socket}

To address the first objective, pain relief was compared between both treatments. The visual analog scale (VAS) was used to evaluate the intensity of pain experienced after the application of PRF and aspirin cones. VAS is a horizontal line with an eleven-point numeric range. It is labeled from zero to 10, with zero indicating no pain and 10 indicating the worst pain possible; therefore, a higher VAS score represents a worse outcome. Patients assessed their pain using VAS once before the treatment and twice afterwards (at $24 \mathrm{~h}$ and $48 \mathrm{~h}$ after treatment). 


\subsection{Assessing the Impact of PRF on Bacterial Activity in Extraction Wounds}

To address the second objective, the number of bacteria in each tooth extraction wound was analyzed after application of PRF or aspirin cones. Outcomes were obtained for aerobic and anaerobic bacteria, streptococci, enterococci, and lactic acid bacilli. Samples for microbiological evaluation were taken when pain was evaluated, once before treatment and twice (at $24 \mathrm{~h}$ and $48 \mathrm{~h}$ ) after treatment.

The swabs for the sample collection were first placed for $10 \mathrm{~s}$ on the surface of the wounds and then placed in tubes containing $2 \mathrm{~mL}$ of $0.85 \%$ sodium chloride solution reduced with cysteine hydrochloride. All bacteria were incubated at $37^{\circ} \mathrm{C}$. The anaerobic bacteria were cultured on dehydrated Shaedler Anaerobe Agar (NutriSelect ${ }^{\circledR}$ Plus) for 48 h, whereas the aerobic bacteria were cultured on Brain Heart Infusion Agar (NutriSelect ${ }^{\circledR}$ Plus) and incubated for $24 \mathrm{~h}$. Streptococci were grown on an Azide Blood Agar Base (NutriSelect ${ }^{\circledR}$ Plus), which was incubated in an atmosphere enriched with carbon dioxide for $48 \mathrm{~h}$, whereas the lactic acid bacilli were cultured on Rogosa Agar (GranuCult ${ }^{\circledR}$ ) and incubated in anaerobic conditions for $24 \mathrm{~h}$. Once the incubation period was complete, all bacterial colonies were counted on individual substrates. The number of bacteria in each subgroup (anaerobic bacteria, aerobic bacteria, streptococci, and lactic acid bacilli) was determined per $1 \mathrm{~mL}$ of bacterial emulsion after accounting for the degree of dilution.

\subsection{Statistical Methods}

Continuous variables were described as arithmetic means with standard deviations, medians, minimum and maximum values, range (difference between minimum and maximum values), and first and third quartiles (denoted by Q1 and Q3).

The results are presented in boxplots wherein each whisker extends from the corresponding quartile to the largest/smallest value no further than $1.5^{*}$ interquartile range (IQR) from the quartile. The IQR is the distance between the first and third quartiles.

Normality of distribution was verified using the Shapiro-Wilk test. Since the assumption of normality was violated in a number of cases, nonparametric Wilcoxon matched-pairs signed-rank test was performed to detect differences in distributions of scalar variables between treatments. A one-sample Wilcoxon test was also used to check whether distributions were symmetrical around zero. If necessary, continuity correction was used. A $p$-value of 0.05 or less was considered significant and was flagged in tables with an asterisk. All calculations and graphs were made using the R package v3.4.4.

\section{Results}

\subsection{Patient Characteristics}

The study group consisted of 30 patients, of whom $12(40 \%)$ were women and 18 $(60 \%)$ were men. The youngest and oldest study participants were 18 and 64 years old, respectively. Half of the group was at least 33 years old, and the average age was 37.8 years. No values were missing in the dataset.

\subsection{Influence of Treatment on Intensity of Pain}

Summary statistics for the intensity of pain experienced after the first diagnosis of dry socket resembled the statistics for the second diagnosis. At both diagnoses, the patients' scores varied from 5 to 9 points, and the mean score was close to the median value of 7 .

Figure 1 shows the differences in pain assessed by each patient. 


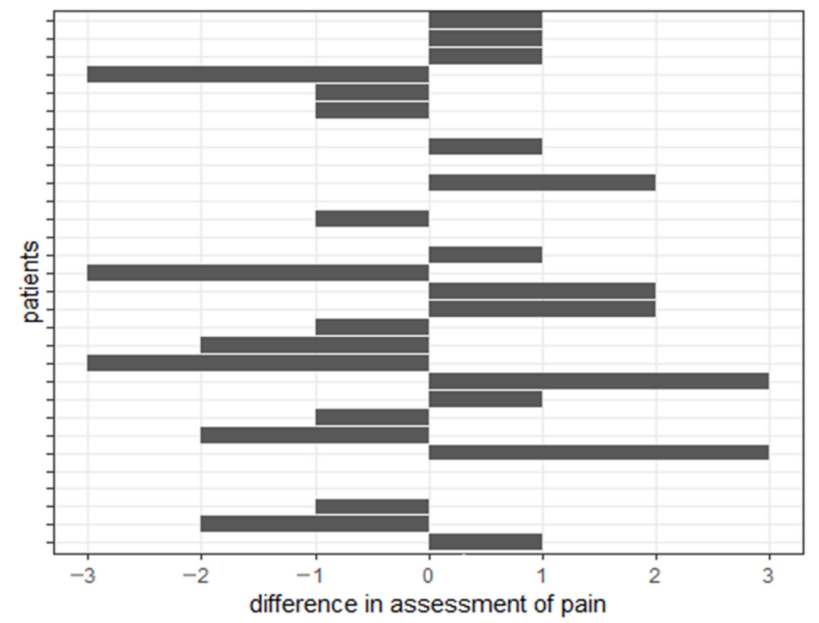

Figure 1. Differences in patients' assessments of pain before treatments.

Negative values indicate that pain intensity was higher before treatment with aspirin cones, while positive values indicate that pain intensity was higher before treatment with PRF. Few values of zero imply that it was seldom for study participants to identically describe the pain before application of either intervention. However, the hypothesis that the distribution of pain scores are similar before both treatments should not be rejected $(p=0.838)$.

At $24 \mathrm{~h}$ after treatment with either intervention, the intensity of pain decreased by up to 4 points or remained the same. The average and median pain relief were higher for the treatment with PRF (Table 1). Pain relief during the first $24 \mathrm{~h}$ was significantly higher after treatment with PRF than with aspirin cones $(p=0.003)$.

Table 1. Pain relief at $24 \mathrm{~h}$ after treatment.

\begin{tabular}{cccccccccc}
\hline Treatment & Mean & Standard Deviation & Median & Min & Max & Range & Q1 & Q3 \\
\hline Nipas & 1.07 & 1.17 & 1 & 0 & 4 & 4 & 0 & 1.75 \\
\hline PRF & 2.10 & 1.12 & 2 & 0 & 4 & 4 & 1 & 3.00 \\
\hline
\end{tabular}

Pain reduction after treatment with aspirin cones was also less perceivable during the next $24 \mathrm{~h}$ (at $48 \mathrm{~h}$ after surgery); the average decrease was equal to 1.1. Contrastingly, application of PRF resulted in the mean pain relief amounting to 2 points at $48 \mathrm{~h}$ after extraction. Once again, the difference between the two treatments was statistically significant $(p=0.011)$ (Table 2).

Table 2. Pain relief at $48 \mathrm{~h}$ after treatment.

\begin{tabular}{cccccccccc}
\hline Treatment & Mean & Standard Deviation & Median & Min & Max & Range & Q1 & Q3 \\
\hline Nipas & 1.1 & 0.96 & 1 & 0 & 3 & 3 & 0 & 2 \\
\hline PRF & 2.0 & 1.49 & 2 & 0 & 5 & 5 & 1 & 3 \\
\hline
\end{tabular}

\subsection{Influence of Treatment on Bacteria Levels in Wounds}

\subsubsection{Bacterial Concentrations}

Figure 2 shows that both treatments resulted in a lower concentration of aerobic bacteria. The decrease took place within the first $24 \mathrm{~h}$ and was slightly larger in wounds treated with PRF. 


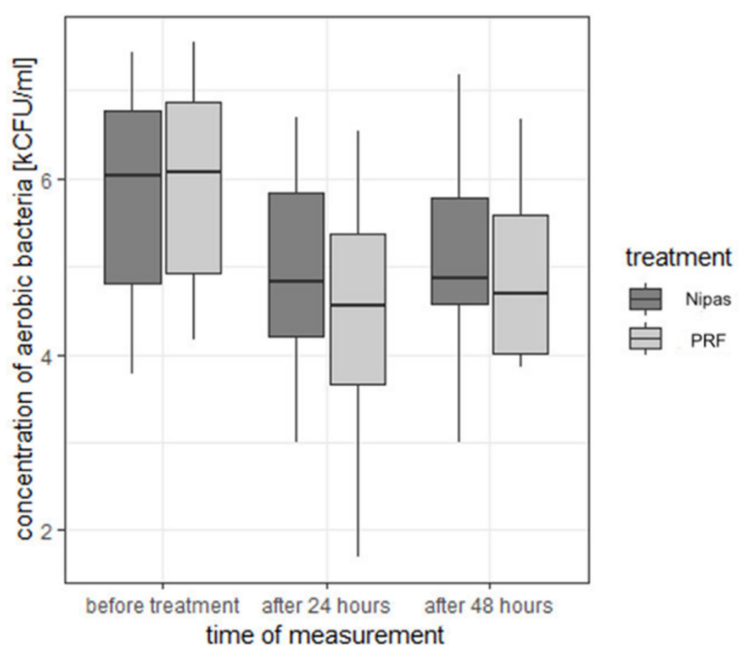

Figure 2. Concentrations of aerobic bacteria.

Similar patterns were observed in concentrations of anaerobic bacteria and streptococci, as shown in Figures 3 and 4. For instance, the mean concentration of streptococci before the application of PRF was equal to $5.52 \times 10^{3} \mathrm{CFU} / \mathrm{mL}$ and dropped to $3.96 \times 10^{3} \mathrm{CFU} / \mathrm{mL}$ within $24 \mathrm{~h}$ following treatment.

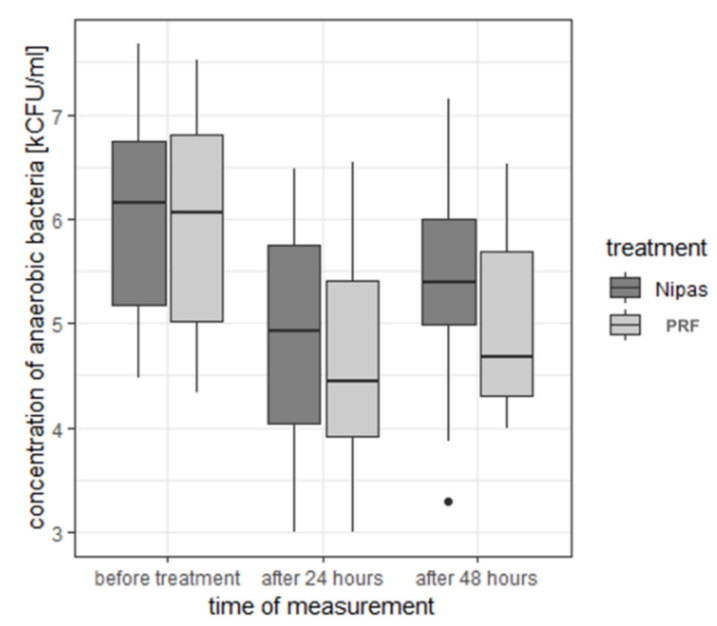

Figure 3. Concentrations of anaerobic bacteria.

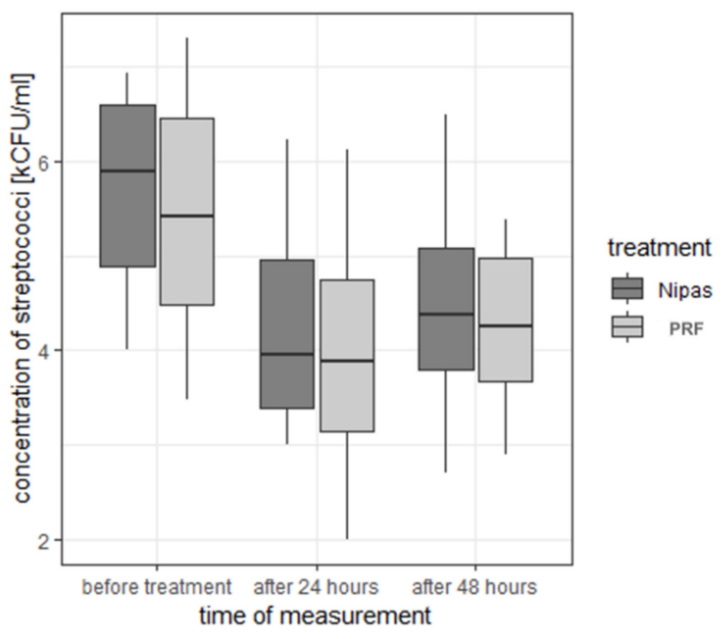

Figure 4. Concentrations of streptococci. 
Variations in the concentrations of lactic acid bacilli differed from the patterns seen in other subgroups. Their concentration after treatment with PRF was the only parameter for which average growth within the first $24 \mathrm{~h}$ was recorded, as shown in Figure 5.

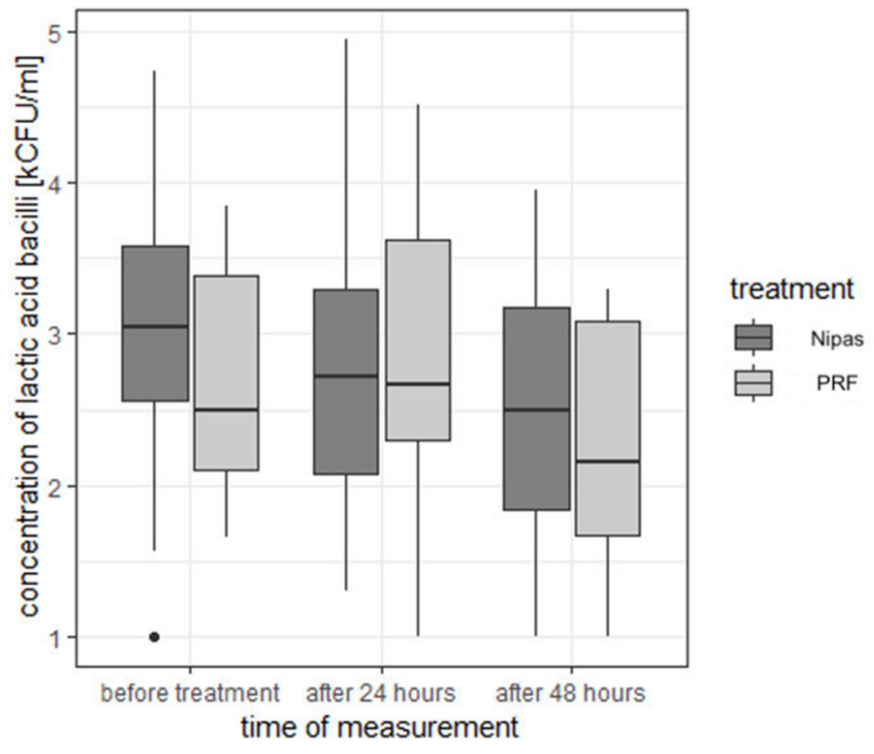

Figure 5. Concentrations of lactic acid bacilli.

There were noticeable differences in the level of enterococci between samples taken at 24 and $48 \mathrm{~h}$ after the treatments, as shown in Figure 6.

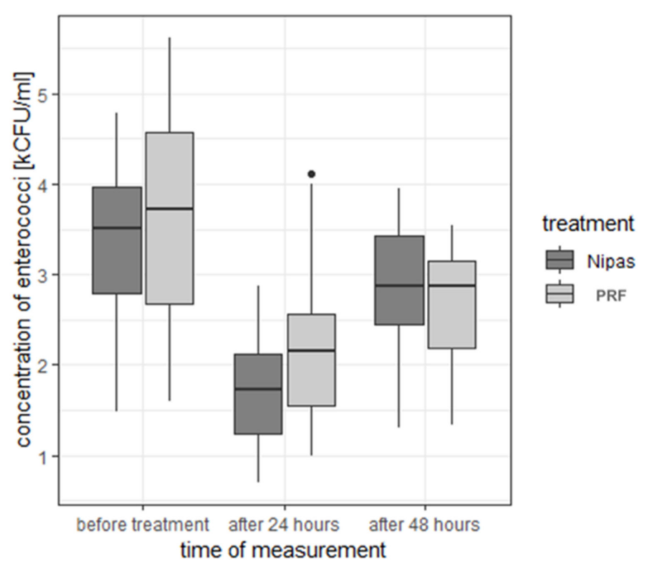

Figure 6. Concentrations of enterococci.

The summary statistics are presented in Table 3. 
Table 3. Summary statistics for concentration of bacteria $(\mathrm{kCFU} / \mathrm{mL})$.

\begin{tabular}{|c|c|c|c|c|c|c|c|c|c|c|}
\hline $\begin{array}{l}\text { Type of } \\
\text { Bacteria }\end{array}$ & $\begin{array}{c}\text { Time of } \\
\text { Measurement }\end{array}$ & Treatment & Mean & $\begin{array}{l}\text { Standard } \\
\text { Deviation }\end{array}$ & Median & Min & Max & Range & Q1 & Q3 \\
\hline \multirow{6}{*}{$\begin{array}{c}\text { aerobic } \\
\text { bacteria }\end{array}$} & \multirow{2}{*}{ before treatment } & Nipas & 5.83 & 1.080 & 6.03 & 3.78 & 7.43 & 3.65 & 4.81 & 6.77 \\
\hline & & PRF & 5.88 & 1.051 & 6.07 & 4.16 & 7.55 & 3.39 & 4.92 & 6.86 \\
\hline & \multirow{2}{*}{$\begin{array}{l}24 \mathrm{~h} \text { after } \\
\text { treatment }\end{array}$} & Nipas & 4.96 & 1.040 & 4.83 & 3.00 & 6.70 & 3.70 & 4.21 & 5.83 \\
\hline & & PRF & 4.50 & 1.220 & 4.56 & 1.70 & 6.54 & 4.84 & 3.67 & 5.37 \\
\hline & \multirow{2}{*}{$\begin{array}{l}48 \mathrm{~h} \text { after } \\
\text { treatment }\end{array}$} & Nipas & 5.12 & 1.030 & 4.87 & 3.00 & 7.18 & 4.18 & 4.57 & 5.78 \\
\hline & & PRF & 4.85 & 0.853 & 4.68 & 3.85 & 6.68 & 2.83 & 4.00 & 5.58 \\
\hline \multirow{6}{*}{$\begin{array}{c}\text { anaerobic } \\
\text { bacteria }\end{array}$} & \multirow{2}{*}{ before treatment } & Nipas & 6.07 & 0.963 & 6.16 & 4.48 & 7.68 & 3.20 & 5.17 & 6.75 \\
\hline & & PRF & 5.94 & 0.989 & 6.05 & 4.33 & 7.53 & 3.20 & 5.01 & 6.80 \\
\hline & \multirow{2}{*}{$\begin{array}{l}24 \mathrm{~h} \text { after } \\
\text { treatment }\end{array}$} & Nipas & 4.96 & 1.010 & 4.93 & 3.00 & 6.48 & 3.48 & 4.05 & 5.75 \\
\hline & & PRF & 4.66 & 0.998 & 4.45 & 3.00 & 6.54 & 3.54 & 3.92 & 5.42 \\
\hline & \multirow{2}{*}{$\begin{array}{l}48 \mathrm{~h} \text { after } \\
\text { treatment }\end{array}$} & Nipas & 5.46 & 0.966 & 5.40 & 3.30 & 7.15 & 3.85 & 4.98 & 6.00 \\
\hline & & PRF & 4.95 & 0.764 & 4.68 & 4.00 & 6.52 & 2.52 & 4.30 & 5.70 \\
\hline \multirow{6}{*}{ streptococci } & \multirow{2}{*}{ before treatment } & Nipas & 5.74 & 0.938 & 5.89 & 4.00 & 6.92 & 2.92 & 4.89 & 6.58 \\
\hline & & PRF & 5.52 & 1.069 & 5.42 & 3.48 & 7.30 & 3.82 & 4.49 & 6.45 \\
\hline & \multirow{2}{*}{$\begin{array}{l}24 \mathrm{~h} \text { after } \\
\text { treatment }\end{array}$} & Nipas & 4.27 & 1.028 & 3.96 & 3.00 & 6.23 & 3.23 & 3.39 & 4.95 \\
\hline & & PRF & 3.96 & 1.148 & 3.88 & 2.00 & 6.12 & 4.12 & 3.13 & 4.74 \\
\hline & \multirow{2}{*}{$\begin{array}{l}48 \mathrm{~h} \text { after } \\
\text { treatment }\end{array}$} & Nipas & 4.41 & 0.882 & 4.37 & 2.70 & 6.49 & 3.79 & 3.79 & 5.07 \\
\hline & & PRF & 4.29 & 0.750 & 4.25 & 2.89 & 5.38 & 2.49 & 3.68 & 4.97 \\
\hline \multirow{6}{*}{ enterococci } & \multirow{2}{*}{ before treatment } & Nipas & 3.31 & 0.810 & 3.50 & 1.48 & 4.78 & 3.30 & 2.79 & 3.97 \\
\hline & & PRF & 3.64 & 1.240 & 3.73 & 1.60 & 5.62 & 4.02 & 2.67 & 4.57 \\
\hline & \multirow{2}{*}{$\begin{array}{l}24 \mathrm{~h} \text { after } \\
\text { treatment }\end{array}$} & Nipas & 1.71 & 0.621 & 1.73 & 0.70 & 2.88 & 2.18 & 1.23 & 2.12 \\
\hline & & PRF & 2.21 & 0.778 & 2.16 & 1.00 & 4.11 & 3.11 & 1.55 & 2.56 \\
\hline & \multirow{2}{*}{$\begin{array}{l}48 \mathrm{~h} \text { after } \\
\text { treatment }\end{array}$} & Nipas & 2.85 & 0.627 & 2.88 & 1.30 & 3.95 & 2.65 & 2.45 & 3.42 \\
\hline & & PRF & 2.67 & 0.606 & 2.87 & 1.33 & 3.54 & 2.21 & 2.19 & 3.16 \\
\hline \multirow{6}{*}{$\begin{array}{l}\text { lactic acid } \\
\text { bacilli }\end{array}$} & \multirow{2}{*}{ before treatment } & Nipas & 3.05 & 0.914 & 3.04 & 1.00 & 4.74 & 3.74 & 2.56 & 3.59 \\
\hline & & PRF & 2.69 & 0.722 & 2.50 & 1.65 & 3.85 & 2.20 & 2.10 & 3.38 \\
\hline & \multirow{2}{*}{$\begin{array}{l}24 \mathrm{~h} \text { after } \\
\text { treatment }\end{array}$} & Nipas & 2.75 & 0.897 & 2.72 & 1.30 & 4.95 & 3.65 & 2.07 & 3.29 \\
\hline & & PRF & 2.86 & 0.933 & 2.67 & 1.00 & 4.51 & 3.51 & 2.30 & 3.62 \\
\hline & \multirow{2}{*}{$\begin{array}{l}48 \mathrm{~h} \text { after } \\
\text { treatment }\end{array}$} & Nipas & 2.53 & 0.835 & 2.50 & 1.00 & 3.95 & 2.95 & 1.84 & 3.18 \\
\hline & & PRF & 2.22 & 0.734 & 2.15 & 1.00 & 3.29 & 2.29 & 1.67 & 3.08 \\
\hline
\end{tabular}

\subsubsection{Differences in Bacteria Concentration}

PRF application decreased the concentration of aerobic bacteria within the first $24 \mathrm{~h}$ in all cases. The decline in mean and median concentrations of aerobic bacteria was less prominent for treatment with aspirin cones, but both interventions reduced the concentrations of aerobic bacteria in a statistically significant manner (both $p$-values $<0.001$ ). The change in the distribution of bacterial concentration during the first $24 \mathrm{~h}$ significantly differed between the two treatments $(p=0.001)$.

Within $24 \mathrm{~h}$ of the application of aspirin cones, the average increase in the concentration of aerobic bacteria was $0.168 \times 10^{3} \mathrm{CFU} / \mathrm{mL}$. Moreover, there was no evidence that the values were not distributed symmetrically around zero $(p=0.103)$ (Figure 7). 


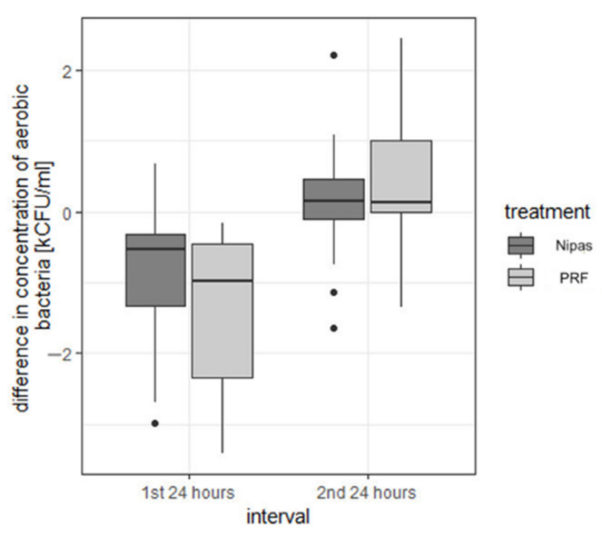

Figure 7. Differences in concentrations of aerobic bacteria.

Contrastingly, the concentration of anaerobic bacteria in all patients' samples reduced within $24 \mathrm{~h}$ after aspirin cone placement. The variations in the concentrations of anaerobic bacteria did not significantly differ between the two treatments on follow-up at $24 \mathrm{~h}$ or $48 \mathrm{~h}$. All four variables presented in Figure 8 are asymmetrically distributed around zero.

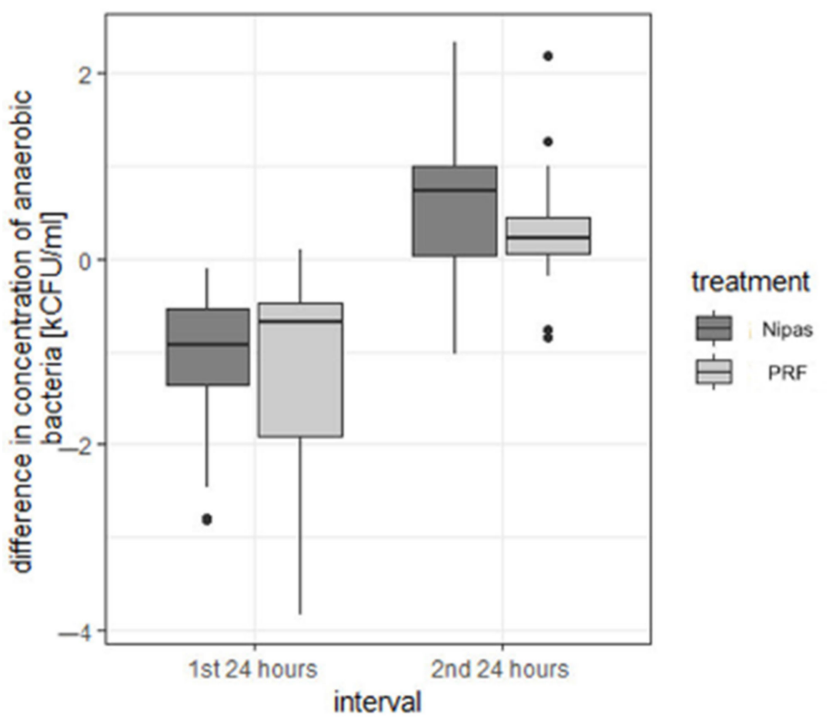

Figure 8. Differences in the concentrations of anaerobic bacteria.

The changes in concentrations of streptococci at $48 \mathrm{~h}$ follow-up after treatment with aspirin cones significantly differed from changes in the concentrations observed at the same time interval after PRF application $(p=0.01)$. The hypothesis that differences in the treatment with aspirin cones were not distributed symmetrically around zero should not be rejected; however, the $p$-value $(p=0.072)$ was only slightly higher than the assumed significance level. It may be worth noting that the outliers observed in Figure 9 (minimum values for differences at $48 \mathrm{~h}$ follow-up) were obtained in the same patient (id 16) for both treatments. 


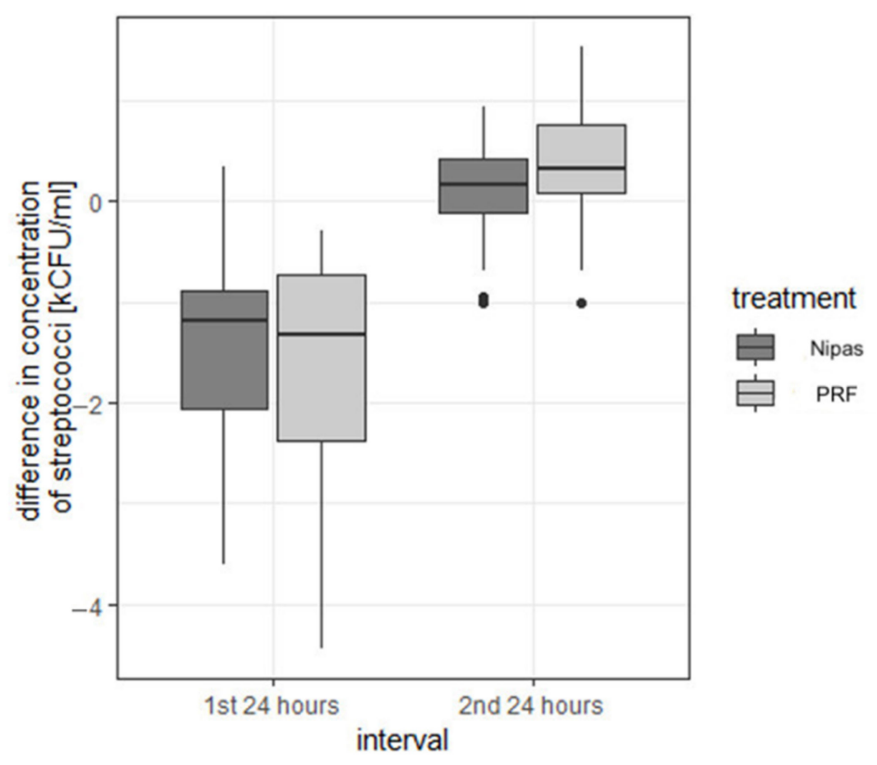

Figure 9. Differences in concentrations of streptococci.

The variations in enterococci concentrations significantly differed between the two treatments at $48 \mathrm{~h}$ follow-up. Similar declines in the first $24 \mathrm{~h}$ were followed by an increase in concentration that was more evident after aspirin cone placement, as can be seen from Figure 10.

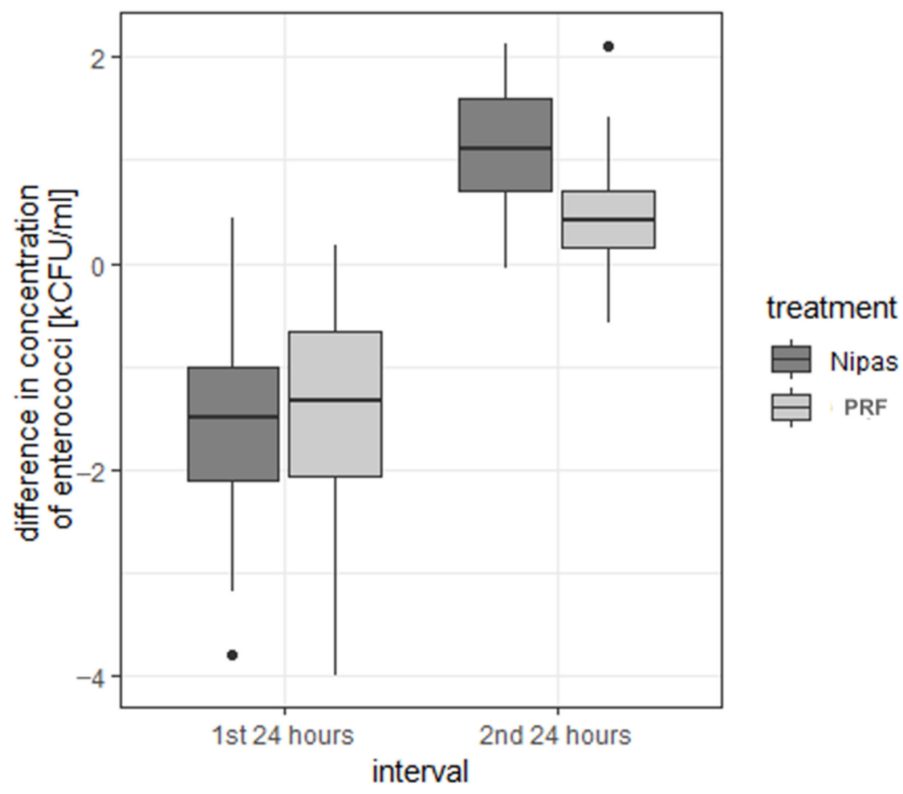

Figure 10. Differences in concentrations of enterococci.

The distributions for lactic acid bacilli did not resemble the distributions of other parameters. Interquartile ranges were narrower; therefore, more outliers occurred. The examined treatments were significantly different in both time intervals ( $p$-values $<0.001$ ). After PRF application, a mean increase of $0.175 \times 10^{3} \mathrm{CFU} / \mathrm{mL}$ was recorded at first, and then an average decrease of $0.642 \times 10^{3} \mathrm{CFU} / \mathrm{mL}$ occurred. The concentrations of lactic acid bacilli declined in most cases after aspirin cone placement (Figure 11). The summary statistics are presented in Table 4. 


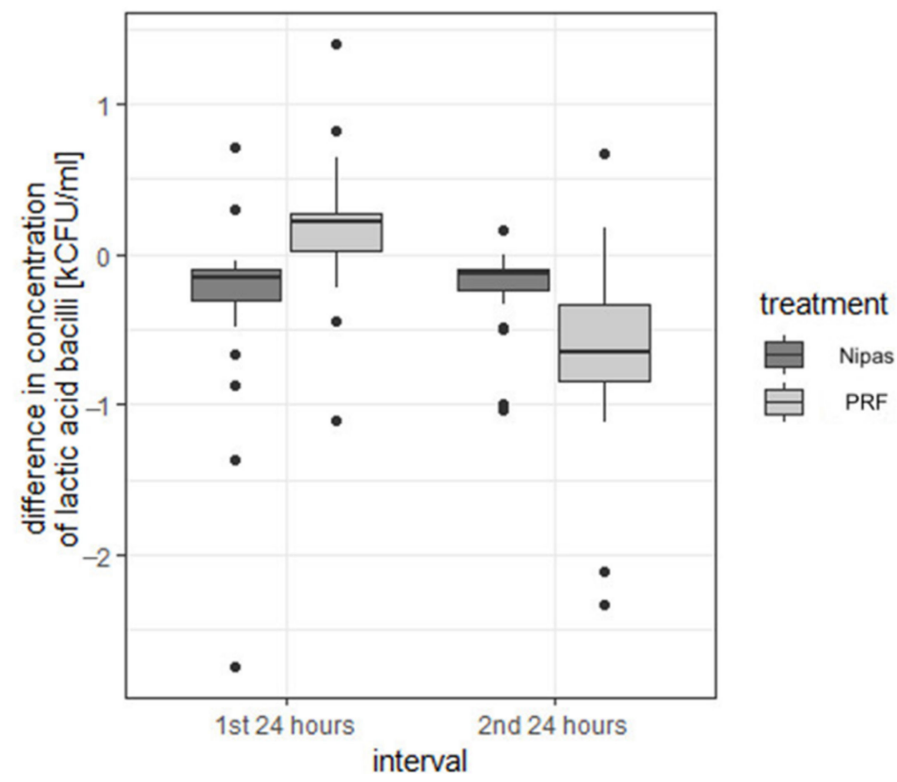

Figure 11. Differences in concentrations of lactic acid bacilli.

Table 4. Summary statistics for changes in concentration of bacteria $(\mathrm{kCFU} / \mathrm{mL})$.

\begin{tabular}{|c|c|c|c|c|c|c|c|c|c|c|}
\hline $\begin{array}{l}\text { Type of } \\
\text { Bacteria }\end{array}$ & Interval & Treatment & Mean & $\begin{array}{l}\text { Standard } \\
\text { Deviation }\end{array}$ & Median & Min & $\operatorname{Max}$ & Range & Q1 & Q3 \\
\hline \multirow{4}{*}{$\begin{array}{l}\text { aerobic } \\
\text { bacteria }\end{array}$} & \multirow{2}{*}{ first $24 \mathrm{~h}$} & Nipas & -0.876 & 0.874 & -0.540 & -2.98 & 0.67 & 3.65 & -1.320 & -0.323 \\
\hline & & PRF & -1.379 & 1.079 & -0.975 & -3.41 & -0.16 & 3.25 & -2.350 & -0.447 \\
\hline & \multirow{2}{*}{ second $24 \mathrm{~h}$} & Nipas & 0.168 & 0.710 & 0.145 & -1.65 & 2.22 & 3.87 & -0.097 & 0.458 \\
\hline & & PRF & 0.347 & 0.963 & 0.130 & -1.35 & 2.45 & 3.80 & -0.007 & 1.008 \\
\hline \multirow{4}{*}{$\begin{array}{c}\text { anaerobic } \\
\text { bacteria }\end{array}$} & \multirow{2}{*}{ first $24 \mathrm{~h}$} & Nipas & -1.105 & 0.779 & -0.920 & -2.80 & -0.11 & 2.69 & -1.360 & -0.545 \\
\hline & & PRF & -1.279 & 1.109 & -0.680 & -3.83 & 0.10 & 3.93 & -1.900 & -0.485 \\
\hline & \multirow{2}{*}{ second $24 \mathrm{~h}$} & Nipas & 0.492 & 0.795 & 0.730 & -1.02 & 2.33 & 3.35 & 0.035 & 0.990 \\
\hline & & PRF & 0.284 & 0.556 & 0.210 & -0.85 & 2.18 & 3.03 & 0.050 & 0.440 \\
\hline \multirow{4}{*}{ streptococci } & \multirow{2}{*}{ first $24 \mathrm{~h}$} & Nipas & -1.469 & 0.884 & -1.180 & -3.60 & 0.34 & 3.94 & -2.058 & -0.895 \\
\hline & & PRF & -1.559 & 1.052 & -1.330 & -4.44 & -0.30 & 4.14 & -2.383 & -0.735 \\
\hline & \multirow{2}{*}{ second $24 \mathrm{~h}$} & Nipas & 0.141 & 0.493 & 0.170 & -1.00 & 0.94 & 1.94 & -0.115 & 0.432 \\
\hline & & PRF & 0.325 & 0.529 & 0.320 & -1.01 & 1.54 & 2.55 & 0.085 & 0.767 \\
\hline \multirow{4}{*}{ enterococci } & \multirow{2}{*}{ first $24 \mathrm{~h}$} & Nipas & -1.597 & 0.932 & -1.495 & -3.78 & 0.45 & 4.23 & -2.095 & -0.995 \\
\hline & & PRF & -1.433 & 1.090 & -1.320 & -3.99 & 0.17 & 4.16 & -2.065 & -0.663 \\
\hline & \multirow{2}{*}{ second $24 \mathrm{~h}$} & Nipas & 1.137 & 0.514 & 1.120 & -0.04 & 2.13 & 2.17 & 0.697 & 1.590 \\
\hline & & PRF & 0.459 & 0.509 & 0.420 & -0.57 & 2.10 & 2.67 & 0.160 & 0.698 \\
\hline \multirow{4}{*}{$\begin{array}{l}\text { lactic acid } \\
\text { bacilli }\end{array}$} & \multirow{2}{*}{ first $24 \mathrm{~h}$} & Nipas & -0.306 & 0.575 & -0.155 & -2.74 & 0.71 & 3.45 & -0.302 & -0.103 \\
\hline & & PRF & 0.175 & 0.411 & 0.210 & -1.10 & 1.40 & 2.50 & 0.025 & 0.272 \\
\hline & \multirow{2}{*}{ second $24 \mathrm{~h}$} & Nipas & -0.218 & 0.256 & -0.135 & -1.03 & 0.16 & 1.19 & -0.240 & -0.100 \\
\hline & & PRF & -0.642 & 0.575 & -0.655 & -2.33 & 0.67 & 3.00 & -0.848 & -0.335 \\
\hline
\end{tabular}

\subsection{Influence of Other Factors}

Wilcoxon signed-rank tests were performed to determine whether pain assessment and bacterial concentrations depended on the patients' sex, but no statistically significant results were obtained. 
The study sample was divided into two groups according to age (younger and older than the median value of 32.5 years) and re-analyzed. The results did not significantly differ between the two groups.

\subsection{Summary of Results}

Within the first $24 \mathrm{~h}$ after treatment, the mean VAS scale score was greater by 1 point after PRF application, indicating that PRF application brought more pain relief than aspirin cone placement. This difference was statistically significant. Similar results were obtained on follow-up at $48 \mathrm{~h}$.

The study of bacteria concentrations in post-extraction wounds revealed other differences between treatments. The application of PRF resulted in a significantly higher reduction in aerobic bacteria concentration at $24 \mathrm{~h}$ follow-up, a significantly greater increase in streptococci concentration at $48 \mathrm{~h}$ follow-up, a significantly smaller increase in enterococci concentration at $48 \mathrm{~h}$ follow-up, an average increase instead of a decrease in lactic acid bacilli concentration at $24 \mathrm{~h}$ follow-up, and a significantly greater decrease in lactic acid bacilli concentration at $48 \mathrm{~h}$ follow-up. Neither pain assessment nor bacteria concentrations depended on the patients' sex or age.

\section{Discussion}

In the light of the results presented in this paper, we conclude that our initial hypothesis, where the properties of PRF surpass those of acetylsalicylic cones, is confirmed, especially in reference to pain relief after application. This seems to be the most important practical advantage for a patient suffering from severe pain.

Overall, the distinct reduction in pain observed in our study is similar to that observed by other researchers who applied PRF in diagnosed alveolar osteitis $[5,10,15]$. However, Mozzatti et al. [16], who used this material after a third molar extraction and assessed pain using the VAS scale from the first to seventh day post application, stated that, although the VAS score decreased over time, the difference was statistically significant $(p<0.05)$ only on the seventh day. According to our study, a $p$-value of 0.003 implied that pain relief during the first $24 \mathrm{~h}$ after treatment with PRF was significantly high. Our findings comply with those of Haraji et al. [17] who conducted a split-mouth study of PRF versus placebo and showed that the intensity of post-extraction pain was significantly less in the study group, starting from first $24 \mathrm{~h}$ after PRF application. Our finding that the pain relief was significantly lower with aspirin cones than with PRF is in contrast with the results of Pal, Singh and Verma [13], who studied the comparison between zinc oxide eugenol dressing and gelatin sponge soaked in PRF for dry socket treatment. They found that symptomatic pain relief was faster in the group treated with zinc oxide eugenol dressing starting from day 1 of the application.

PRF may show a potential antimicrobial effect because it contains platelets with a high concentration of growth factors $[10,18]$, such as platelet-derived growth factor, transforming growth factor beta 1, platelet-derived endothelial growth factor, vascular endothelial growth factor, and platelet-derived angiogenesis factor. Platelet-derived growth factor (PDGF) occurs in two isoforms, PDGF-AB and PDGF-BB, and is responsible for the angiogenesis and proliferation of stem cells. This protein is present in the highest concentration and plays a significant role in the fast healing of oral wounds [19,20]. According to Serafini et al., the level of PDGF-AB increases 7 days after collection, whereas PDGF-BB is released at high levels just after preparation, with a second increase after 14 days [20]. The role of the transforming growth factor beta (TGF- $\beta$ ) should also be emphasized-it is a factor that affects many functions of cells, especially their proliferation, differentiation and apoptosis. These roles are crucial for healing wounds; during injured tissues regeneration, there are many types of cells that must be stimulated in order to achieve a successful healing result [21]. The TGF- $\beta$ appears to be usually stimulated 7 days after collection [20]. Finally, the vascular endothelial growth factor (VEGF) plays a key role in blood vessels formation, either angiogenesis or vasculogenesis [22]. It was reported that VEGF particularly increases 
7 days after collection and decreases after the next 7 days. [20]. In the context of this information, the PDGF-BB is the factor with the highest-released concentration in the period of our study.

It is worth mentioning that there is also an exceptional variety of PRF-L-PRF (leukocyte-platelet rich fibrin) which is considered to be a second generation of platelet concentrates and was introduced by Dohan et al. in 2006 [23]. Using a special centrifugation technique, a fibrin network is obtained with almost $95 \%$ of the platelets embedded in it, which ensures the slow release of growth factors. This property not only enhances the healing of soft tissues but also provides a better bone quality, as reported by Serafini et al. [24] in the context of post-extraction socket treatment before implant placement. In our study, the use of L-PRF is worthy of a further investigation in the area of alveolar osteitis treatment.

It has been reported that platelet-rich plasma (PRP) might have an antimicrobial effect against Staphylococcus aureus, Escherichia coli, and Klebsiella pneumonia, which makes it potentially effective in postoperative infections. However, as the properties of PRP materials strongly depend on the concentration of platelets and time of placement, authors are still unsure of this potential [25,26]. According to the study of Badade et al. [27], who evaluated the antimicrobial activities of PRP and PRF against periodontal disease-associated bacteria, PRP was capable of inhibiting Porphyromonas gingivalis and Aggregatibacter actinomycetemcomitans; however, PRF was unable to inhibit these bacteria. A probable explanation for this is that, although the components of PRP and PRF are similar, PRP needs the presence of calcium chloride to activate the platelets. A different study identified calcium chloride as a probable cause for the difference in the antimicrobial action of both materials [28].

Kour et al. [29] showed that PRF application reduced the antibacterial activity to a greater extent than the other platelet concentrates did. A possible explanation for this is that the concentration of platelets and cytokines is higher in PRF than in whole blood because they became embedded in the autologous fibrin matrix and were released once the fibrin meshwork disintegrated [30,31]. In our opinion, observation over a longer period of time is necessary to fully confirm the antimicrobial activity of PRF.

We are fully aware of some limitations that our research may have. First of all, our results are based on the observations of only one medical center; moreover, the requirements set by the protocol of our study were very restrictive, which resulted in a relatively small study group. In addition, we compared PRF with only one possible method of alveolar osteitis treatment (acetylsalicylic acid cones, which are the most commonly used in our country). It would have been interesting, in terms of further research, to conduct a comparison with other available treatment methods.

\section{Conclusions}

In conclusion, our study suggests that PRF application is beneficial for relieving pain, which is the most bothersome symptom of dry socket. The concentration of bacteria in post-extraction wounds corresponded with the results of pain relief. As PRF can be easily prepared, even in clinical settings with limited resources, it is a useful treatment alternative for dry socket.

Author Contributions: A.J.-N.: Conceptualization, Methodology, Data curation, Writing-Original draft preparation, Reviewing and Editing. D.C.: Data curation, Formal Analysis, Investigation. All authors have read and agreed to the published version of the manuscript.

Funding: The article was funded by Medical University of Lodz as a part of statutory activity no. 503/2-163-01/503/01.

Institutional Review Board Statement: The study was performed after approval from the Bioethical Committee of Medical University of Lodz (RNN/369/18/KE), in compliance with Helsinki Declaration. ClinicalTrials.gov Identifier: NCT04476121.

Informed Consent Statement: Informed consent was obtained from all subjects involved in the study. 
Data Availability Statement: The data presented in this study are available on request from the corresponding author. The data are not publicly available due to the fact that part of the data is subject to further research.

Conflicts of Interest: The authors declare no conflict of interest. The funders had no role in the design of the study; in the collection, analyses, or interpretation of data; in the writing of the manuscript, or in the decision to publish the results.

\section{References}

1. Taberner-Vallverdú, M.; Nazir, M.; Sánchez-Garcés, M.Á.; Gay-Escoda, C. Efficacy of different methods used for dry socket management: A systematic review. Med. Oral Patol. Oral Cir. Bucal 2015, 20, e633-e639. [CrossRef] [PubMed]

2. Ansari, A.; Joshi, S.; Garad, A.; Mhatre, B.; Bagade, S.; Jain, R. A Study to Evaluate the Efficacy of Honey in the Management of Dry Socket. Contemp. Clin. Dent. 2019, 10, 52-55. [CrossRef] [PubMed]

3. Lone, P.A.; Ahmed, S.W.; Prasad, V.; Ahmed, B. Role of turmeric in management of alveolar osteitis (dry socket): A randomised clinical study. J. Oral Biol. Craniofacial Res. 2018, 8, 44-47. [CrossRef] [PubMed]

4. Mamoun, J. Dry Socket Etiology, Diagnosis, and Clinical Treatment Techniques. J. Korean Assoc. Oral Maxillofac. Surg. 2018, 44, 52-58. [CrossRef] [PubMed]

5. Sharma, A.; Aggarwal, N.; Rastogi, S.; Choudhury, R.; Tripathi, S. Effectiveness of platelet-rich fibrin in the management of pain and delayed wound healing associated with established alveolar osteitis (dry socket). Eur. J. Dent. 2017, 11, 508-513. [CrossRef] [PubMed]

6. Xiang, X.; Shi, P.; Zhang, P.; Shen, J.; Kang, J. Impact of platelet-rich fibrin on mandibular third molar surgery recovery: A systematic review and meta-analysis. BMC Oral Health 2019, 19, 163. [CrossRef] [PubMed]

7. Kolokythas, A.; Olech, E.; Miloro, M. Alveolar osteitis: A comprehensive review of concepts and controversies. Int. J. Dent. 2010, 2010, 249073. [CrossRef] [PubMed]

8. Kamal, A.; Salman, B.; Abdul Razak, N.H.; Qabbani, A.A.; Samsudin, A.R. The Efficacy of Concentrated Growth Factor in the Healing of Alveolar Osteitis: A Clinical Study. Int. J. Dent. 2020, 2020, 9038629. [CrossRef]

9. Faizel, S.; Thomas, S.; Yuvaraj, V.; Prabhu, S.; Tripathi, G. Comparision between neocone, alvogyl and zinc oxide eugenol packing for the treatment of dry socket: A double blind randomised control trial. J. Maxillofac. Oral Surg. 2015, 14, 312-320. [CrossRef]

10. Rastogi, S.; Choudhury, R.; Kumar, A.; Manjunath, S.; Sood, A.; Upadhyay, H. Versatility of platelet rich fibrin in the management of alveolar osteitis-A clinical and prospective study. J. Oral Biol. Craniofacial Res. 2018, 8, 188-193. [CrossRef]

11. Chakravarthi, S. Platelet rich fibrin in the management of established dry socket. J. Korean Assoc. Oral Maxillofac. Surg. 2017, 43, 160-165. [CrossRef] [PubMed]

12. Kamal, A.; Salman, B.; Razak, N.H.A.; Samsudin, A.B.R. A Comparative Clinical Study between Concentrated Growth Factor and Low-Level Laser Therapy in the Management of Dry Socket. Eur. J. Dent. 2020, 14, 613-620. [CrossRef] [PubMed]

13. Pal, U.S.; Singh, B.P.; Verma, V. Comparative evaluation of zinc oxide eugenol versus gelatin sponge soaked in plasma rich in growth factor in the treatment of dry socket: An initial study. Contemp. Clin. Dent. 2013, 4, 37-41. [CrossRef] [PubMed]

14. Keshini, M.P.; Shetty, S.K.; Sundar, S.; Chandan, S.N.; Manjula, S. Assessment of Healing Using Alvogyl and Platelet Rich Fibrin in Patients with Dry Socket-An Evaluative Study. Ann. Maxillofac. Surg. 2020, 10, 320-324. [CrossRef] [PubMed]

15. Al-Hamed, F.S.; Tawfik, M.A.-M.; Abdelfadil, E.; Al-Saleh, M.A.Q. Efficacy of Platelet-Rich Fibrin After Mandibular Third Molar Extraction: A Systematic Review and Meta-Analysis. J. Oral Maxillofac. Surg. 2017, 75, 1124-1135. [CrossRef] [PubMed]

16. Mozzati, M.; Martinasso, G.; Pol, R.; Polastri, C.; Cristiano, A.; Muzio, G.; Canuto, R. The impact of plasma rich in growth factors on clinical and biological factors involved in healing processes after third molar extraction. J. Biomed. Mater. Res. A 2010, 95, 741-746. [CrossRef] [PubMed]

17. Haraji, A.; Lassemi, E.; Motamedi, M.H.; Alavi, M.; Adibnejad, S. Effect of plasma rich in growth factors on alveolar osteitis. Natl. J. Maxillofac. Surg. 2012, 3, 38-41. [CrossRef]

18. Chatterjee, A.; Debnath, K. Comparative evaluation of growth factors from platelet concentrates: An in vitro study. J. Indian Soc. Periodontol. 2019, 23, 322-328. [CrossRef]

19. Fredriksson, L.; Li, H.; Eriksson, U. The PDGF family: Four gene products form five dimeric isoforms. Cytokine Growth Factor Rev. 2004, 15, 197-204. [CrossRef]

20. Serafini, G.; Lopreiato, M.; Lollobrigida, M.; Lamazza, L.; Mazzucchi, G.; Fortunato, L.; Mariano, A.; D’abusco, A.S.; Fontana, M.; De Biase, A. Platelet Rich Fibrin (PRF) and Its Related Products: Biomolecular Characterization of the Liquid Fibrinogen. J. Clin. Med. 2020, 9, 1099. [CrossRef]

21. Massagué, J.; Xi, Q. TGF- $\beta$ control of stem cell differentiation genes. FEBS Lett. 2012, 586, 1953-1958. [CrossRef] [PubMed]

22. Ferrara, N.; Houck, K.; Jakeman, L.; Leung, D.W. Molecular and biological properties of the vascular endothelial growth factor family of proteins. Endocr. Rev. 1992, 13, 18-32. [CrossRef] [PubMed]

23. Dohan, D.M.; Choukroun, J.; Diss, A.; Dohan, S.L.; Dohan, A.; Mouhyi, J.; Gogly, B. Platelet-rich fibrin (PRF): A second-generation platelet concentrate. Part II: Platelet-related biologic features. Oral Surg. Oral Med. Oral Pathol. Oral Radiol. Endodontol. 2006, 101, e45-e50. [CrossRef] [PubMed] 
24. Serafini, G.; Lollobrigida, M.; Fortunato, L.; Mazzucchi, G.; Lamazza, L.; Di Nardo, D.; Vozza, I.; Riminucci, M.; De Biase, A. Postextractive Alveolar Ridge Preservation Using L-PRF: Clinical and Histological Evaluation. Case Rep. Dent. 2020, 2020, 5073519. [CrossRef] [PubMed]

25. Anitua, E.; Alonso, R.; Girbau, C.; Aguirre, J.J.; Muruzabal, F.; Orive, G. Antibacterial effect of plasma rich in growth factors $\left(\right.$ PRGF $^{\circledR}$-Endoret $\left.{ }^{\circledR}\right)$ against Staphylococcus aureus and Staphylococcus epidermidis strains. Clin. Exp. Dermatol. 2012, 37, 652-657. [CrossRef] [PubMed]

26. Drago, L.; Bortolin, M.; Vassena, C.; Taschieri, S.; Del Fabbro, M. Antimicrobial activity of pure platelet-rich plasma against microorganisms isolated from oral cavity. BMC Microbiol. 2013, 13, 47. [CrossRef]

27. Badade, P.S.; Mahale, S.A.; Panjwani, A.A.; Vaidya, P.D.; Warang, A.D. Antimicrobial effect of platelet-rich plasma and platelet-rich fibrin. Indian J. Dent. Res. 2016, 27, 300-304. [CrossRef]

28. Nagaoka, S.; Murata, S.; Kimura, K.; Mori, T.; Hojo, K. Antimicrobial activity of sodium citrate against Streptococcus pneumoniae and several oral bacteria. Lett. Appl. Microbiol. 2010, 51, 546-551. [CrossRef]

29. Kour, P.; Pudakalkatti, P.S.; Vas, A.M.; Das, S.; Padmanabhan, S. Comparative Evaluation of Antimicrobial Efficacy of Plateletrich Plasma, Platelet-rich Fibrin, and Injectable Platelet-rich Fibrin on the Standard Strains of Porphyromonas gingivalis and Aggregatibacter actinomycetemcomitans. Contemp. Clin. Dent. 2018, 9 (Suppl. 2), S325-S330. [CrossRef]

30. Dohan, D.M.; Choukroun, J.; Diss, A.; Dohan, S.L.; Dohan, A.J.; Mouhyi, J.; Gogly, B. Platelet-rich fibrin (PRF): A secondgeneration platelet concentrate. Part I: Technological concepts and evolution. Oral Surg. Oral Med. Oral Pathol. Oral Radiol. Endodontology 2006, 101, e37-e44. [CrossRef]

31. Saini, R.; Saini, S.; Sharma, S. Therapeutics of stem cells in periodontal regeneration. J. Nat. Sci. Biol. Med. $2011,2,38-42$. [CrossRef] [PubMed] 